\title{
1997 Sivas population health survey household situation
}

\section{7 sivas nufus sağlık araştırması hane hallkı dlurumu}

\author{
Naim Karagöz ${ }^{1}$, Güllay Koçoğlu ${ }^{1}$
}

Sivas Cumhuriyet Üniversitesi Tıp Fakültesi, Tıp Eğitimi Anabilim Dalı, Sivas, Türkiye

${ }^{2}$ Sivas Cumhurivet Üniversitesi Tıp Fakültesi, Halk Sağlı̆ı̆ Anabilim Dalı, Sivas, Türkive

Corresponding author: Naim Karagöz, MD, Sivas Cumhuriyet Üniversitesi Tıp Fakültesi, Tıp Eğitimi Anabilim Dalı, Sivas, Türkiye

E-mail: naimkaragoz66@gmail.com

Received/Accepted: May 27, 2019 /June 26, 2019

Conflict of interest: There is not a conflict of interest.

\section{SUMMARY}

The basis of planning, essential of high-quality management, in the field of health is to know the health criteria related to the area covered by the service unit. This study was carried out to meet the mentioned needs in Sivas province. The study was conducted in 870 households in the province of Sivas between $15^{\text {th }}$ November 1996 and $7^{\text {th }}$ March 1997, and the sample universe was all of Sivas city. Urban and rural areas in the sample selection are separated. The quarters of the city were selected by stratified sampling method. Villages were determined by simple random sampling method after creating a cluster of village groups in rural. In urban and rural areas, houses were determined by simple random sampling method. The questionnaire was obtained by subtracting some questions from the questionnaire form of TNSA 1993. The questionnaire application was made by the midwives of the health centers. $64.4 \%$ of households are in urban areas, $49.6 \%$ of them are male. The average household size is 5.27. $5.7 \%$ of men and $20.4 \%$ of women have no education. $76.5 \%$ of the houses meet the drinking water from the tap water, $70.5 \%$ of the houses are connected to the sewer.

Keywords: Household, health service, Sivas
iD Naim Karagöz

(D) Gülay Koçoğlu

ORCID IDs of the authors: N.K. 0000-0002-6456-1128 G.K. 0000-0001-7357-8098

\section{ÖZET}

Sağlık alanında kaliteli bir yönetimin ihtiyacı olan planlamanın temel dayanağı, bulunulan hizmet biriminin kapsadığı alana ait sağlık ölçütlerini bilmektir. Bu çalışma Sivas İli genelinde belirtilen ihtiyacı karşılamak için gerçekleștirilmiştir. Sivas ilinde 15 Kasım 1996 -7 Mart 1997 tarihleri arasında 870 hanede yürütülen bu araştırmanın evreni Sivas İlinin tamamıdır. Örneklem seçiminde kentsel ve kırsal alanlar ayrılmıştır. Tabakalı örneklem yöntemi ile mahalleler seçilmiştir. Kırsal alan küme köy grupları oluşturulmuş basit rasgele örneklem yöntemi ile görüşülecek köy belirlenmiştir. Kentsel ve kırsal alanda haneler basit rasgele örneklem yöntemiyle belirlenmiştir. Anket metni olarak 1993 T.N.S.A anket formundan bazı sorular çıkarılarak elde edilmiştir. Anket uygulamasını adresin bağlı bulunduğu sağlık ocağı ebeleri yapmıştır. Hanehalkının \%64.4' ü kenttedir, \%49.6' s1 erkektir. Ortalama hanehalkı büyüklüğü 5.27' dir. Erkeklerin \%5.7' sinin, kadınların 20.4' ünün eğitimi yoktur. Evlerin \%76.5'i içme sularını şebeke suyundan karşılamaktadır, \%70.5' inin helası kanalizasyona bağlıdır.

Anahtar sözcükler: Hanehalkı, sağlık hizmeti, Sivas 


\section{INTRODUCTION}

If we want to be efficient and effective in service provision in our age, we need a good organizational structure and high-quality management style. In this context, the Ministry of Health, which is the most comprehensive and the most competent organization currently serving in the field of health, is an institution that is established within the framework of laws ${ }^{1-2}$. Therefore, local managers can do nothing more in terms of correcting the structure of this organization. For organizations to have good governance, they need to have strategic planning, strategic management, and strategic supervision principles ${ }^{3}$.

Recognition of health care managers to the community they provide service and especially those who involve preventive health services is one of the crucial factors affecting the service quality. The criteria used for community recognition are speeds and rates. These are the units of measure developed to determine the levels of death, birth, and other problems related to illness and health in a population. To obtain reliable health criteria, a complete and accurate registration system is needed. If there is no such system or if it is not functioning well, or if more comprehensive information is required, then a regional or national epidemiological research is carried out ${ }^{4}$.

Current management problems in the health field taking place in Turkey are viable also for Sivas, the quality of collected data is decreased because to be forced to serve with insufficient personnel numbers. Therefore, it is not possible to make consistent plans for the future and to set realistic targets. To overcome these problems and to make a more effective contribution to the city and our country's health services, the health survey of Sivas population was planned with the belief that the health problems experienced today would be resolved through recognizing the society with this aspect.

\section{MATERIAL AND METHODS}

The objective of this study is to determine the demographic structure of the community living in this region and the health services, fertility measures, family planning and maternal and child health data and interpreting their health levels by analyzing these data.

The universe of the research conducted between 15 November 1996 and 7 March 1997 includes all the hamlets, villages, towns and districts within the administrative borders of Sivas Province. This universe consists of 639,147 people identified in the June 1996 household survey conducted by the Provincial Directorate of Health of Sivas ${ }^{5}$.

In this research, $\mathrm{t}$ value was used as 1.92 within a $=0.05$ and $\mathrm{d}=0.05$ in the formula used in the sample selection. Several married women aged 15-49 years and the number of people in the population used while calculating $\mathrm{p}$ and $\mathrm{q}$ values. Sivas central district and affiliated 16 district centers constituted the urban universe and towns, villages and hamlets constituted the rural universe. Separate "p" values were calculated for central district, other 16 districts, and rural universe. $\mathrm{P}$ was 0.28 for Sivas center, $\mathrm{p}=0.26$ for district centers and $p=0.22$ for rural population. When these values were formulated, it was $\mathrm{n}=$ 310 for Sivas center, $\mathrm{n}=295$ for district centers and $n=265$ for rural areas. So we had to interview in the central district 310 married women aged 15-49 years and houses, 295 in other district centers with a total of 605 in rural areas and 265 for the urban universe. For the whole universe, we had to interview 870 married women aged 15-49 years and houses.

In the selection of these houses, stratified sampling was performed according to the population of the district centers by taking the 1996 E.T.F (Household Detection Plug) population into consideration. It was calculated how many houses would be interviewed from each district. Then, taking into account the population of the districts, the stratified sampling was made according to the population weight of the districts. The number of houses to be interviewed was calculated for each quarter. Then, by using simple random sampling method, noble and substitute households were determined, as the number of households with the calculated weight was taken into consideration in the E.T.F card number sequence of the relevant quarter (6). The addresses of these houses and the names of the married women aged 15-49 years to be discussed were recorded. In rural areas, the rural areas of Sivas were scattered, and the population density was low, so the cluster was formed by considering the administrative boundaries of the districts with the concern of concentration in a certain region. A village group of about 1000 houses was created, and if the number of houses in the district boundary was less than 1000 , then all villages of that district were accepted as a group. Thus, 54 cluster villages were created in the rural universe. According to the population density of each cluster with stratified sampling, it was calculated how many 15-49 years old married women and houses would be interviewed. A village was 
selected from each cluster with a simple random sample given the clutter of rural areas. If the number of households of the selected village was insufficient, the second village was selected, and the households that we should meet for the clay were determined by simple random sampling method based on E.T.F card numbers, and sufficient households were found. The addresses of these households and the names of the married women aged 15-49 years to be discussed were recorded.

Some of the questions were removed from the 1993 Turkey Population Health Research ${ }^{7}$ (T.P.H.R.) questionnaires and are used as survey text. The height and weight measurements are taken in the questionnaire were made by the Health Handbook for Children of the Ministry of Health ${ }^{8}$. Mothers were measured according to the measurement principles of children over two years old $^{8}$.

To apply the surveys, midwives of health centers and health houses were selected as interviewers. Midwives taking part in the meetings were gathered in the district centers, and the questionnaire application training was given by the researcher. Health center doctors were assigned to the control of the application and the pre-controls of the questionnaires. Head of health group of the district was responsible for logistic support and coordination, they have also made second controls of filled questionnaires. Doctors and heads of health group were trained by the investigator to be efficient and sufficient in the subjects they are assigned to. The collected questionnaires were evaluated after the final controls. The researcher supervised district visits and practices.

This work was carried out with the personnel and logistic support of Sivas Provincial Health Directorate. Since midwives were surveyed, midwives were adequately surveyed, and other measurement tools which used in pregnant-baby follow-up were available in midwife kitbags.
The collected data were finalized by the researcher and uploaded to Epi Info 6.0 program. Some evaluations were made by using the SPSS statistical program.

\section{RESULTS}

\section{KEY FEATURES OF THE HOUSEHOLD AND HOUSEHOLD POPULATION:}

In the study, $64.4 \%$ of the households in Sivas were living in urban areas and $35.6 \%$ in rural areas. $49.6 \%$ of the households are male, and $50.4 \%$ are female. In Sivas province, the 0-4 age group is $12.2 \%$, and the age group $0-14$ is $37.9 \%$. Dependent population over 65 years of age was $2.4 \%$, and the total dependent population was $40.3 \%$. In rural areas, the dependent population is $43.6 \%$, while this value is $39.4 \%$ in urban areas. The rural/urban distribution of households by age groups is given in Table $1 \mathrm{~A}$, and the total distribution of provinces in the province is given in Table 1B.

Table 2 presents the distribution of households according to the size of the household and gender of the head of the family. $98.2 \%$ of heads of family in urban areas and $94.7 \%$ in rural were males. While $47.4 \%$ of households have 4 or fewer people living in urban areas, this situation decreases to $22.3 \%$ in rural areas. The average household size was 4.88 in urban areas, 6.15 in rural areas, and 5.27 in all of the province.

The distribution of the education level of the household population by age groups, place of residence, and gender is shown in Table 3 A-B. $5.7 \%$ of men and $20.4 \%$ of women have no education. The educational status of both males and females varies considerably according to the place of residence, and the proportion of those receiving secondary, high school and above education in urban areas is higher than in rural areas (p: 0.0001, p: 0.00001). Also, women who do not have education in rural areas have higher rates compared to urban areas. 
Table 1 A: Distribution of household population by age groups, place of residence, and gender.

\begin{tabular}{|c|c|c|c|c|c|c|c|c|c|c|c|c|}
\hline \multirow{3}{*}{$\begin{array}{l}\text { Age } \\
\text { Groups } \\
\end{array}$} & \multicolumn{6}{|l|}{ City } & \multicolumn{6}{|l|}{ Rural } \\
\hline & \multirow{2}{*}{\multicolumn{2}{|c|}{\begin{tabular}{|l|l|} 
Male \\
Number $\%$
\end{tabular}}} & \multicolumn{2}{|l|}{ Female } & \multirow{2}{*}{\multicolumn{2}{|c|}{\begin{tabular}{|l|l|}
\multicolumn{2}{|l|}{ Total } \\
Number $\%$
\end{tabular}}} & \multicolumn{2}{|l|}{ Male } & \multicolumn{2}{|c|}{ Female } & \multicolumn{2}{|l|}{ Total } \\
\hline & & & Number & $\%$ & & & Number & $\%$ & Num & & Numl & \\
\hline & 166 & 11.2 & 192 & 13.0 & 358 & 12.1 & 98 & 12.3 & 102 & 12.3 & 200 & 12.3 \\
\hline $5-9$ & 182 & 12.3 & 163 & 11.1 & 345 & 11.7 & 104 & 13.0 & 125 & 15.0 & 229 & 14.1 \\
\hline $10-14$ & 180 & 12.2 & 191 & 12.9 & 371 & 12.6 & 114 & 14.3 & 120 & 14.4 & 234 & 14.3 \\
\hline $15-19$ & 172 & 111.7 & 181 & 12.3 & 353 & 12.0 & 89 & 11.1 & 94 & 11.3 & 183 & 11.1 \\
\hline $20-24$ & 118 & 7.9 & 148 & 10.0 & 266 & 9.0 & 64 & 8.0 & 76 & 9.1 & 140 & 8.6 \\
\hline $25-29$ & 128 & 8.7 & 134 & 9.1 & 262 & 8.9 & 56 & 7.0 & 61 & 7.3 & 117 & 7.2 \\
\hline $30-34$ & 127 & 8.6 & 128 & 8.7 & 255 & 8.6 & 56 & 7.0 & 63 & 7.6 & 119 & 7.3 \\
\hline $35-39$ & 126 & 8.5 & 109 & 7.4 & 235 & 7.9 & 57 & 7.2 & 40 & 4.8 & 97 & 6.0 \\
\hline $40-44$ & 97 & 6.6 & 91 & 6.2 & 188 & 6.4 & 38 & 4.8 & 43 & 5.2 & 81 & 5.0 \\
\hline $45-49$ & 81 & 5.5 & 48 & 3.3 & 129 & 4.4 & 28 & 3.5 & 40 & 4.8 & 68 & 4.2 \\
\hline $50-54$ & 34 & 2.3 & 21 & 1.4 & 55 & 1.9 & 38 & 4.8 & 14 & 1.7 & 52 & 3.2 \\
\hline $55-59$ & 21 & 1.4 & 14 & 0.9 & 35 & 1.2 & 18 & 2.3 & 21 & 2.5 & 39 & 2.4 \\
\hline $60-64$ & 17 & 1.2 & 19 & 1.3 & 36 & 1.2 & 14 & 1.8 & 9 & 1.1 & 23 & 1.4 \\
\hline 65-69 & 12 & 0.8 & 15 & 1.0 & 27 & 0.9 & 10 & 1.3 & 13 & 1.6 & 23 & 1.4 \\
\hline $70-74$ & 5 & 0.3 & 10 & 0.7 & 15 & 0.5 & 4 & 0.5 & 6 & 0.7 & 10 & 0.6 \\
\hline 75-79 & 5 & 0.3 & 5 & 0.3 & 10 & 0.3 & 5 & 0.6 & 1 & 0.1 & 6 & 0.4 \\
\hline $80+$ & 7 & 0.5 & 6 & 0.4 & 13 & 0.4 & 4 & 0.5 & 4 & 0.5 & 8 & 0.5 \\
\hline Total & 1478 & 100.0 & 1475 & 100.0 & 2953 & 100.0 & 797 & 100.0 & 832 & 100.0 & 1629 & 100.0 \\
\hline
\end{tabular}

Table 1 B: Distribution of household population by age groups and gender.

\begin{tabular}{|l|l|l|l|l|l|l|}
\hline \multirow{2}{*}{$\begin{array}{c}\text { Age } \\
\text { Groups }\end{array}$} & Male & \multicolumn{3}{l|}{ Female } & \multicolumn{2}{l|}{ Total } \\
\cline { 2 - 7 } & Number & $\%$ & Number & $\%$ & Number & $\%$ \\
\hline $0-4$ & 264 & 11.6 & 294 & 12.7 & 558 & 12.2 \\
\hline $5-9$ & 286 & 12.6 & 288 & 12.5 & 574 & 12.5 \\
\hline $10-14$ & 294 & 12.9 & 311 & 13.5 & 605 & 13.2 \\
\hline $15-19$ & 261 & 11.5 & 275 & 11.9 & 536 & 11.7 \\
\hline $20-24$ & 182 & 8.0 & 224 & 9.7 & 406 & 8.9 \\
\hline $25-29$ & 184 & 8.1 & 195 & 8.5 & 379 & 8.3 \\
\hline $30-34$ & 183 & 8.0 & 191 & 8.3 & 374 & 8.2 \\
\hline $35-39$ & 183 & 8.0 & 149 & 6.5 & 332 & 7.2 \\
\hline $40-44$ & 135 & 5.9 & 134 & 5.8 & 269 & 5.9 \\
\hline $45-49$ & 109 & 4.8 & 88 & 3.8 & 197 & 4.3 \\
\hline $50-54$ & 72 & 3.2 & 35 & 1.5 & 107 & 2.3 \\
\hline $55-59$ & 39 & 1.7 & 35 & 1.5 & 74 & 1.6 \\
\hline $60-64$ & 31 & 1.4 & 28 & 1.2 & 59 & 1.3 \\
\hline $65-69$ & 22 & 1.0 & 28 & 1.2 & 50 & 1.1 \\
\hline $70-74$ & 9 & 0.4 & 16 & 0.7 & 25 & 0.5 \\
\hline $75-79$ & 10 & 0.4 & 6 & 0.3 & 16 & 0.3 \\
\hline $80+$ & 11 & 0.5 & 10 & 0.4 & 21 & 0.5 \\
\hline Total & 2275 & 100.0 & 2307 & 100.0 & 4582 & 100.0 \\
\hline
\end{tabular}


Table 2: Household composition.

\begin{tabular}{|c|c|c|c|c|c|c|}
\hline \multicolumn{7}{|l|}{ SETTLEMENT } \\
\hline \multirow[t]{2}{*}{ HANE REİSİ } & \multicolumn{2}{|c|}{ City $\mathrm{n}=605$} & \multicolumn{2}{|c|}{ Rural $n=265$} & \multicolumn{2}{|l|}{ Total } \\
\hline & $\overline{\text { Number }}$ & $\%$ & Number & $\%$ & Number & $\%$ \\
\hline Male & 594 & 98.2 & 251 & 94.7 & 845 & 97.1 \\
\hline Female & 11 & 1.8 & 14 & 5.3 & 25 & 2.9 \\
\hline \multicolumn{7}{|l|}{$\begin{array}{l}\text { Usually in the house } \\
\text { Number of inhabitants }\end{array}$} \\
\hline 1 & 2 & 0.3 & 1 & 0.4 & 3 & 0.3 \\
\hline 2 & 27 & 4.5 & 4 & 1.5 & 31 & 3.6 \\
\hline 3 & 79 & 13.1 & 18 & 6.8 & 97 & 11.1 \\
\hline 4 & 179 & 29.5 & 36 & 13.6 & 215 & 24.7 \\
\hline 5 & 134 & 22.1 & 48 & 18.1 & 182 & 20.9 \\
\hline 6 & 96 & 15.9 & 61 & 23.0 & 157 & 18.0 \\
\hline 7 & 46 & 7.6 & 39 & 14.7 & 85 & 9.8 \\
\hline 8 & 24 & 4.0 & 28 & 10.6 & 52 & 6.1 \\
\hline $9+$ & 18 & 3.0 & 30 & 11.3 & 48 & 5.5 \\
\hline Average Size & \multicolumn{2}{|l|}{4.88} & \multicolumn{2}{|l|}{6.15} & \multicolumn{2}{|l|}{5.27} \\
\hline Number of Households & \multicolumn{2}{|l|}{2953} & \multicolumn{2}{|l|}{1629} & \multicolumn{2}{|l|}{4582} \\
\hline
\end{tabular}

Table 3A: The distribution of the highest level of education of the six-year-old and older population by location.

\begin{tabular}{|c|c|c|c|c|c|c|c|c|c|}
\hline EDUCAT & EVEL & & & & & & & & \\
\hline Male* & & & & & & & & & \\
\hline & No traini & & Elementa & y School & econdary & chool & $\begin{array}{l}\text { High } \\
\text { Ahove }\end{array}$ & hool & andTotal \\
\hline Settlement & Number & $\%$ & Number & $\%$ & Number & $\%$ & Number & $\%$ & Number \\
\hline City & 58 & 4.5 & 494 & 38.5 & 252 & 19.7 & 478 & 37.3 & 1282 \\
\hline Rural & 57 & 8.3 & 435 & 63.7 & 105 & 15.4 & 86 & 12.6 & 683 \\
\hline Total & 115 & 5.8 & 929 & 47.3 & 357 & 18.2 & 564 & 28.7 & 1965 \\
\hline Female ** & & & & & & & & & \\
\hline Settlement & Number & & $\%$ Number & $\%$ & Number & $\%$ & Number & & $\%$ Number \\
\hline City & 201 & 16.2 & 616 & 49.7 & 183 & 14.8 & 240 & 19.3 & 1240 \\
\hline Rural & 197 & 28.5 & 440 & 63.7 & 38 & 5.5 & 16 & 2.3 & 691 \\
\hline Total & 398 & 20.4 & 1076 & 55.2 & 221 & 11.3 & 256 & & 13.11951 \\
\hline
\end{tabular}

*x $2: 169.9$ / S.D:3 / P:0.0001**x $2: 178 \_.9 /$ S.D:3 / P:0.00001

Note: Percentages are line percentage

When the educational status was evaluated according to gender, the difference was statistically significant (p: 0.00001). The percentage of males who attend secondary school and receive education in high school and above is higher than women.

Table 4 shows the 6-24 age group from the household population and their school attendance by age group and place of residence. In the 6-24 age group, the rate of participation in urban areas is $59 \% .54 .1 \%$ of those attending school are male, and $45.9 \%$ are female. In this age group, the percentage of those attending school in rural areas is $47.9 \%$ and $53.7 \%$ male and $46.3 \%$ female. 
Table 3: The distribution of the highest level of education by age groups of the six-year-old and over-aged population.

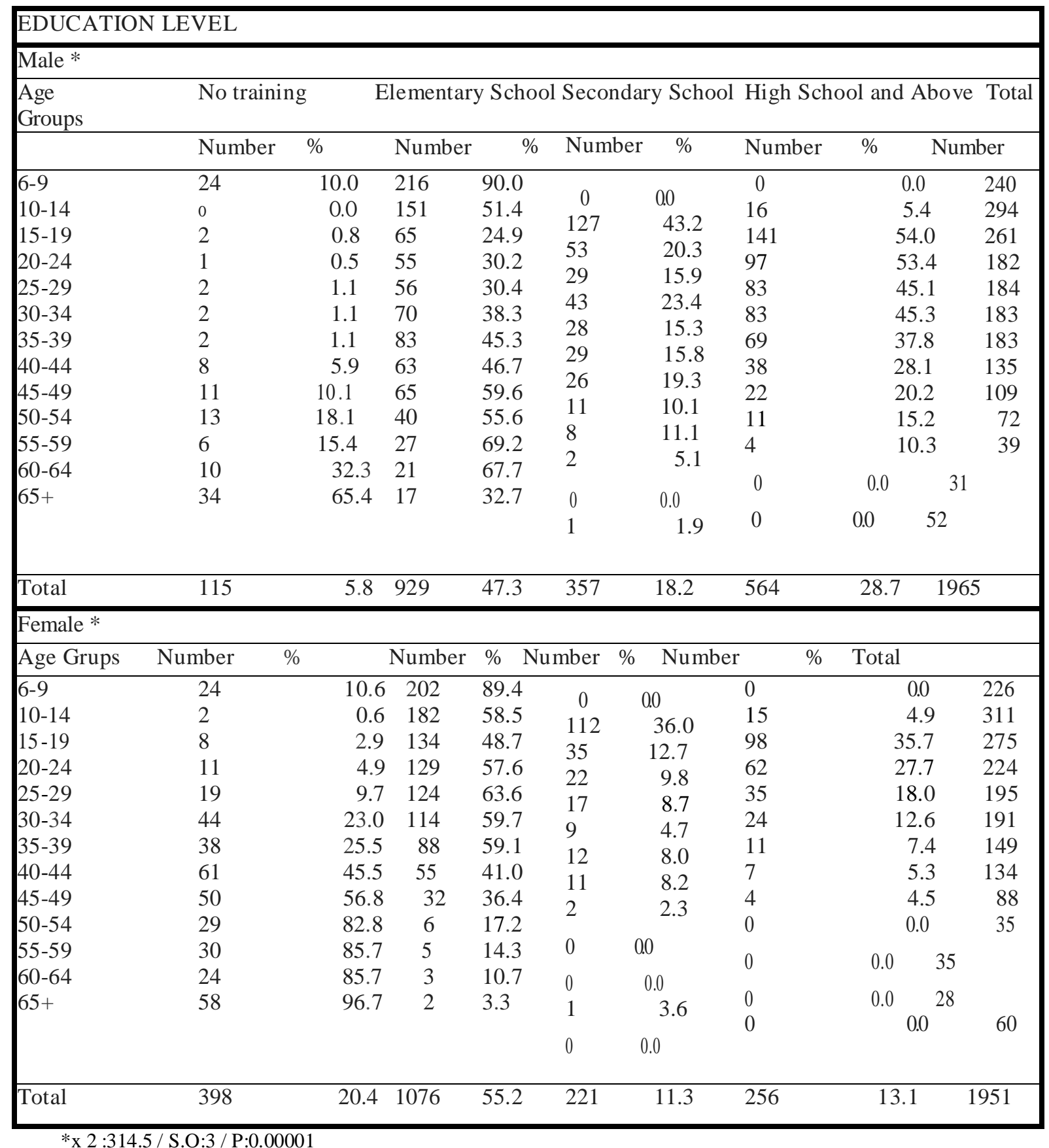

While the male / female ratio of those attending school in the 6-14 age group is close to each other, this rate is increasing in favor of males at the age of 15-24. The difference was statistically significant (p: 0.00001). The difference is that the percentage of those who do not attend school in rural areas is high. 
Table 4: Status of 6-24-year-old households by age group, gender, and school attendance.

\begin{tabular}{|c|c|c|c|c|c|c|c|}
\hline \multirow{2}{*}{$\begin{array}{l}\text { Age } \\
\text { Groups }\end{array}$} & \multirow[t]{2}{*}{ Attendance Status } & \multicolumn{2}{|l|}{ Male } & \multicolumn{2}{|l|}{ Female } & \multirow{2}{*}{ Total } & \multirow{2}{*}{$\% *$} \\
\hline & & Number & $\%$ & Number & $\%$ & & \\
\hline \multirow[t]{2}{*}{$6-9$} & Continuing & 215 & 51.7 & 201 & 48.3 & 416 & 99.5 \\
\hline & Not continuing & 1 & 50.0 & 1 & 50.0 & 2 & 0.5 \\
\hline \multirow[t]{2}{*}{$10-14$} & Continuing & 236 & 52.1 & 217 & 47.9 & 4 & 75.2 \\
\hline & Not continuing & 58 & 38.9 & 91 & 61.1 & 149 & 24.8 \\
\hline \multirow[t]{2}{*}{$15-19$} & Continuing & 101 & 61.6 & 63 & 38.4 & 164 & 38.5 \\
\hline & Not continuing & 158 & 43.6 & 204 & 56.4 & 362 & 61.5 \\
\hline \multirow[t]{2}{*}{$20-24$} & Continuing & 22 & 66.7 & 9 & 33.3 & 31 & 7.9 \\
\hline & Not continuing & 157 & 44.1 & 202 & 55.9 & 359 & 92.1 \\
\hline \multirow[t]{2}{*}{ City } & Continuing & 393 & 54.1 & 334 & 45.9 & $* * 727$ & 59.0 \\
\hline & Not continuing & 216 & 42.7 & 290 & 57.3 & $* * 506$ & 41.0 \\
\hline \multirow[t]{2}{*}{ Rural } & Continuing & 181 & 53.7 & 156 & 46.3 & $* * 337$ & 47.9 \\
\hline & Not continuing & 158 & 43.2 & 208 & 56.8 & **366 & 52.1 \\
\hline Total & & 958 & 49.5 & 988 & 50.5 & 1936 & 100.0 \\
\hline
\end{tabular}

* Percentage of all age groups and settlements among themselves.

Information on the dwellings of the household population and shows the sources of drinking water in Table 5. In Sivas province, the ratio of the households that meet the drinking water at home or in the garden by the domestic water supply was found to be $76.5 \%$, and the rate of those who connected to the sewage system was $70.5 \%$. $79.3 \%$ of households use one or two rooms to sleep. The average number of people per bedroom is 2.6. The flooring of $68.8 \%$ of the houses is concrete or wooden cement on concrete. When the rural and urban dwellings were evaluated in terms of the source of drinking water, the difference was statistically significant ( $P$ : $0.00001)$. The source of the difference is that in the rural area, the wells, the fountains, and the ordinary water used in the garden are seen to be higher than the urban areas. The difference between households and the rural regions was statistically significant (P: 0.00001). The source of the difference is that in rural areas, closed pits, open pits, and non-hull households are seen at higher rates than in urban areas. 
Table 5 : Distribution of households by residential properties and settlements.

\begin{tabular}{|c|c|c|c|c|c|c|}
\hline \multicolumn{7}{|l|}{ SETTLEMENT } \\
\hline \multirow[b]{2}{*}{ Property features } & \multicolumn{2}{|c|}{ Rural } & \multicolumn{3}{|c|}{ Total } & \multirow[b]{2}{*}{$\%$} \\
\hline & Number & $\%$ & Number & $\%$ & Number & \\
\hline \multicolumn{7}{|l|}{ Drinking water supply * } \\
\hline Home / garden water supply & 524 & 86.6 & 141 & 53.2 & 665 & 76.5 \\
\hline Common mains water & 69 & 11.4 & 52 & 19.6 & 121 & 13.9 \\
\hline Home / yard well & 4 & 0.7 & 8 & 3.0 & 12 & 1.4 \\
\hline Spring / fountain & 4 & 0.7 & 64 & 24.2 & 68 & 7.8 \\
\hline Tanker water & 2 & 0.3 & 00 & 0.0 & 2 & 0.2 \\
\hline Bottle of water & 2 & 0.3 & & 0.0 & 2 & 0.2 \\
\hline \multicolumn{7}{|l|}{ Toilet facilities ** } \\
\hline Depending on sewer & 549 & 90.7 & 64 & 24.2 & 613 & 70.5 \\
\hline Closed pit & 47 & 7.8 & 153 & 57.7 & 200 & 23.0 \\
\hline Open Pit & 9 & 1.5 & 45 & 17.0 & 54 & 6.2 \\
\hline No Whole & 0 & 0.0 & 3 & 1.1 & 3 & 0.3 \\
\hline \multicolumn{7}{|l|}{ Number of rooms used to sleep } \\
\hline 1 room & 160 & 26.4 & 65 & 24.5 & 225 & 25.9 \\
\hline 2 room & 336 & 55.5 & 128 & 48.3 & 464 & 53.4 \\
\hline 3 room & 91 & 15.1 & 59 & 22.3 & 150 & 17.2 \\
\hline 4 room & 17 & 2.8 & 11 & 4.2 & 28 & 3.2 \\
\hline 5 and above room & 1 & 0.2 & 2 & 0.7 & 3 & 0.3 \\
\hline $\begin{array}{l}\text { Falling average person per } \\
\text { bedroom }\end{array}$ & 2.5 & & 2.9 & & 2.6 & \\
\hline \multicolumn{7}{|l|}{ Floor Covering } \\
\hline Soil & 40 & 6.6 & 96 & 36.2 & 136 & 15.6 \\
\hline Wood & 328 & 54.2 & 76 & 28.7 & 404 & 46.4 \\
\hline Parquet & 60 & 9.9 & 2 & 0.8 & 62 & 7.2 \\
\hline Concrete & 113 & 18.7 & 81 & 30.6 & 194 & 22.4 \\
\hline Carpet Marley & 10 & 1.6 & 5 & 1.9 & 15 & 1.7 \\
\hline Mosaic & 46 & 7.6 & 4 & 1.5 & 50 & 5.7 \\
\hline Other & 7 & 1.2 & 0 & 0.0 & 7 & 0.8 \\
\hline & 1 & 0.2 & 1 & 0.3 & 2 & 0.2 \\
\hline Total & 605 & & 265 & & 870 & \\
\hline Number of households & 2953 & & 1629 & & 4582 & \\
\hline
\end{tabular}

x 2: 156.9 / S.D:2 / P:0.00001. **x 2: 393.9/ S.D:2/ P:0.00001.

Note: Percentages are based on the total number of households.

The distribution of the durable goods in the households according to the settlements is given in Table 6. Of the families in Sivas, $89.8 \%$ had refrigerators, $76.6 \%$ had furnaces, $75.1 \%$ had washing machines, $68.6 \%$ had vacuum cleaners,
96.2\% had televisions, $83.8 \%$ had radio cassette recorders, and $80.0 \%$ had telephones. 
Table 6: Distribution of households with selected durable consumer goods by location.

\begin{tabular}{|c|c|c|c|c|c|c|c|}
\hline \multicolumn{8}{|l|}{ Settlement } \\
\hline \multicolumn{2}{|c|}{ City } & \multicolumn{2}{|c|}{ Rural } & \multicolumn{3}{|c|}{ Total } & \\
\hline Durable consumer goods & Number & $\%$ & Number & $\%$ & Number & $\%$ & \\
\hline Refrigerator & 589 & & 97.4 & 238 & 89.8 & 827 & 95.1 \\
\hline Bakery & 509 & & 84.1 & 157 & 59.2 & 666 & 76.6 \\
\hline Washing machine & 515 & & 85.1 & 139 & 52.5 & 654 & 75.1 \\
\hline Dishwasher & 80 & & 13.2 & 2 & 0.8 & 82 & 9.4 \\
\hline Vacuum cleaner & 500 & & 82.6 & 97 & 36.6 & 597 & 68.6 \\
\hline Television & 591 & & 97.7 & 246 & 92.8 & 837 & 96.2 \\
\hline Video & 82 & & 13.6 & 15 & 5.7 & 97 & 11.1 \\
\hline Radio cassette player $* * *$ & 514 & & 85.0 & 215 & 81.1 & 729 & 83.8 \\
\hline Stereo & 194 & & 32.1 & 38 & 14.3 & 232 & 26.7 \\
\hline Telephone $* * * *$ & 511 & & 84.5 & 185 & 69.8 & 696 & 80.0 \\
\hline Car & 180 & & 29.8 & 52 & 19.6 & 232 & 26.7 \\
\hline Computer & 19 & & 3.1 & 0 & 0.0 & 19 & 2.2 \\
\hline More than 30 books & 260 & & 43.0 & 32 & 12.1 & 292 & 33.7 \\
\hline Total Household & 605 & & & 265 & & 870 & \\
\hline Total households & 2953 & & & 1629 & & $\overline{4582}$ & \\
\hline
\end{tabular}

Note: Percentages are based on the total number of households.

The presence of durable consumer goods in households varies significantly from residential areas. The proportion of those who did not have refrigerator, television, and telephone was significantly higher in rural areas (P: 0.00001, P: 0.001, P: 0.00001).
The distribution of women, according to their basic characteristics, is shown in Table 7. According to this, the percentage of women who have marriages in Sivas is $4.0 \%$. $22.4 \%$ of women have not received any education, $58.3 \%$ have attended or attended primary school. 
Table 7: Distribution of married women according to selected basic characteristics.

\begin{tabular}{|l|l|l|}
\hline Key feature. N=870 & Number of women & $\%$ \\
\hline Age groups & 34 & \\
\hline $15-19$ & 136 & 4.0 \\
$20-24$ & 183 & 15.6 \\
$25-29$ & 184 & 21.0 \\
$30-34$ & 144 & 21.1 \\
$35-39$ & 115 & 16.6 \\
$40-44$ & 74 & 13.2 \\
$45-49$ & & 8.5 \\
\hline Marital status & 852 & \\
\hline The married & 13 & 97.9 \\
Widow & 1 & 1.5 \\
Divorced & 4 & 0.1 \\
The yard lives & & 0.5 \\
\hline Education status & 195 & \\
\hline No training & 507 & 22.4 \\
Attended primary school & 65 & 58.3 \\
Secondary school & 103 & 7.5 \\
High School or above & & 11.8 \\
educated & & \\
\hline Settlement & 605 & 30.5 \\
\hline City & 265 & \\
Rural & & \\
\hline
\end{tabular}

The availability of women to the mass media is presented in Table 8. As it can be seen in the table, $95.6 \%$ of women in Sivas are watching television at least once a week, $77.8 \%$ of them listen to the radio at least once, and $42.9 \%$ of them read a newspaper at least once a week. This ranking does not change in the city and the countryside, but only the rates change. As the level of education increases, the rate of reading of newspapers increases, but the priority of watching television continues. In the distribution of women according to age groups, it is noteworthy that the primary means of mass communication is television. 
Table 8: According to selected basic characteristics, married women have access to mass media

\begin{tabular}{|c|c|c|c|c|c|c|c|}
\hline \multirow{3}{*}{$\begin{array}{c}\text { Key feature. } \\
\text { Age groups }\end{array}$} & \multicolumn{7}{|c|}{ At least once a week } \\
\hline & \multirow{2}{*}{\begin{tabular}{|l} 
Read a \\
Number
\end{tabular}} & \multirow{2}{*}{$\begin{array}{l}\text { newspaper } \\
\%\end{array}$} & \multicolumn{2}{|c|}{ Watching TV } & \multicolumn{2}{|c|}{$\begin{array}{c}\text { Radio } \\
\text { Listener }\end{array}$} & \multirow{2}{*}{$\begin{array}{l}\text { Number of } \\
\text { women }\end{array}$} \\
\hline & & & Number & $\%$ & Number & $\%$ & \\
\hline $15-19$ & 17 & 50.0 & 30 & 88.2 & 31 & 91.2 & 34 \\
\hline $20-24$ & 70 & 51.5 & 132 & 97.1 & 105 & 77.2 & 136 \\
\hline $25-29$ & 92 & 50.3 & 179 & 97.8 & 145 & 79.2 & 183 \\
\hline $30-34$ & 79 & 42.9 & 171 & 92.9 & 148 & 80.4 & 184 \\
\hline $35-39$ & 59 & 41.0 & 138 & 95.8 & 112 & 77.8 & 144 \\
\hline $40-44$ & 36 & 31.3 & 109 & 94.8 & 86 & 74.8 & 115 \\
\hline $45-49$ & 20 & 27.0 & 72 & 97.3 & 50 & 67.6 & 74 \\
\hline \multicolumn{8}{|l|}{$\begin{array}{l}\text { Education } \\
\text { status }\end{array}$} \\
\hline No training & 8 & 4.1 & 178 & 91.3 & 119 & 61.0 & 195 \\
\hline $\begin{array}{l}\text { Attended primary } \\
\text { school }\end{array}$ & 223 & 44.0 & 487 & 96.1 & 412 & 81.3 & 507 \\
\hline Secondary school & 48 & 73.8 & 64 & 98.5 & 56 & 86.2 & 65 \\
\hline $\begin{array}{l}\text { High School or } \\
\text { above educated }\end{array}$ & 94 & 91.3 & 103 & 100.0 & 90 & 87.4 & 103 \\
\hline \multicolumn{8}{|l|}{ Settlement } \\
\hline City & 318 & 52.6 & 586 & 96.9 & 488 & 80.7 & 605 \\
\hline Rural & 55 & 20.8 & 246 & 92.8 & 189 & 71.3 & 265 \\
\hline Total & 373 & 42.9 & 832 & 95.6 & 677 & 77.8 & 870 \\
\hline
\end{tabular}

Note: Percentages are based on the number of women.

\section{DISCUSSION}

Basic indicators of household in this research and Turkey $^{7}$ in 1993 as compared Table 9 'is also presented.

$59 \%$ of the population in the 1990 census in Turkey live in urban areas ${ }^{9}$. In the 1990 census, the city population in Sivas was $49.8 \%$. Urban population ratio was $76 \%$ in the USA, $35 \%$ in Pakistan, $71 \%$ in Bulgaria at $1997^{11}$. According to the population in 1997 in Sivas in mid-year, the rate of urban population was $53.5 \%$. In the summer months in Sivas, a population movement from the other cities to Sivas and from an urban area to the rural area. The survival rate in Sivas is close to the rate of Turkey and has been increasing over the years. 1997 Sivas $39.3 \%{ }^{12}$ year-dependent species population in the midpopulation in the province of Sivas is close to the dependent population in general of Turkey. According to mid-year population 1997 in Sivas average household size of $4.73{ }^{12}$, according to the 1990 census, the average household in Sivas $5.66^{10}$. Although reduction to the average household in the province of Sivas, not reduced to 1993 average of Turkey seems. 1993 Sivas rates of women and men in education appear to be on the general level of education of Turkey. 
Table 9: Sivas province and Turkey in 1993 the main indicators of overall households.

\begin{tabular}{|l|l|l|}
\hline Sivas & 1997 & Türkiye 1993 \\
\hline Residence in the city (\%) & 64.4 & 60.4 \\
Dependent Population (\%) & 40.3 & 42.1 \\
Average Household Size & 5.3 & 4.5 \\
Domestic / In-House Network Water (\%) & 76.5 & 62.9 \\
Sewage Whole (\%) & 70.5 & 59.4 \\
Falling Per Bedroom & & \\
Average Number of People & 2.6 & 2.5 \\
Household With Refrigerator (\%) & 95.1 & 87.4 \\
Household with TV (\%) & 96.2 & 86.7 \\
Male without Training (\%) & 5.7 & 13.0 \\
Women without Education (\%) & 20.4 & 29.1 \\
Women Watching Television (\%) & 95.6 & 89.0 \\
\hline
\end{tabular}

In a study conducted by Dr.Yoldaçcan et al. In Doğankent, Adana, the rate of use of network water was found to be $79 \%$, wastewater was discharged to $69.3 \%$, and the sanitary rate was found to be $47.9 \%{ }^{13}$. According to the $1997 \mathrm{ETF}$ mid-year survey, the percentage of those who meet drinking water in the city of Sivas is $79.1 \%$. The proportion of households connected to sewerage was $60.2 \%$ in $1993^{12}$. This gives us the status of the households of Sivas in Turkey shows that the overall good conditions. In our study, according to 1997 ETF data, high rate of drainage due to the sewage system is the population with high population density in rural areas, and there is a sewage system. Also, health personnel may use the cards from previous years when filling in the ETF, which may be caused by negligent behavior in updating the data of the household when updating the data of the persons on these cards.

Durable consumer goods available rates across households in Sivas is higher than households in 1993 Turkey. The living conditions of Sivas Province seems to be over than average of general living conditions of Turkey at $19933^{7}$. Women use television first line and secondly radio among mass media. Newspaper is the least preferred mass media. As the level of education increases, even if the reading habits have increased, it cannot go ahead without using television and radio. In 1993, women in Turkey to use the mass media were showing the same sort of values is compatible with Sivas ${ }^{7}$.

\section{CONCLUSION}

- In 1997, 64.4\% of the households in Sivas were in urban areas, and $49.6 \%$ of them were male. The average household size is 5.27. The rate of households that meet the drinking water at home or in the garden is $76.5 \%$. The rate of households connected to sewerage is $70.5 \%$.

- $5.7 \%$ of males and $20.4 \%$ of females have no education. $4.5 \%$ of males and $16.2 \%$ of females in urban areas; $8.3 \%$ of males and $28.5 \%$ of females in rural areas did not receive an education.

- There were refrigerators in $89.8 \%$ of households in Sivas, furnaces in $76.6 \%$, washing machines in $75.1 \%$, vacuum cleaners in $68.6 \%$, televisions in $96.2 \%$, radio tapes in $83.8 \%$, phones in $80.0 \%$.

\section{SUGGESTIONS.}

- Healthy drinking water should be provided in all settlements, and toilets should be made healthy to protect human health.

- Because most of the women watch television and listen to the radio in second place, it should be paid attention to make sure that the propaganda to be made in the health sector is done according to these principles. 


\section{REFERENCES}

1. The Law on the Socialization of Health Services, 1961. Health Legislation. Hacettepe Publication Association. Ankara, 1987

2. Decree on the Organization and Duties of the Ministry of Health, 1983. Health Legislation. Hacettepe Publication Association. Ankara, 1987

3.Acar A. Strategy Management. Ministry of Health 1. Health Project Management Training Program 1. Booklet. M.E.T.U. Ankara, 1996

4. Tezcan S. Epidemiology. Hacettepe Public Health Foundation. Publication No: 92/1. Ankara, 1992

5. Sivas Governorship Provincial Health Directorate. Health Directorate Statistics Yearbook 1996. Sivas, 1997

6. Sümbüloğlu K. Sümbüloğlu V. Biostatistics. Hatiboglu Publishing House. Ankara, 1990, 3rd Edition

7. Hacettepe Institute of Population Studies. TNSA 1993. Ankara, 1994
8. T.C. Ministry of Health A.Ç.S.A.P. Gn. M. Child Health Programs Handbook. Ankara, 1995

9. T.C. Ministry of Health. Health Statistics, 1996.Ankara, 1997

10. Turkey Union of Chambers and Commodity Exchanges. Development Strategy of. Ankara, 1997

11. Unicef. The State of the World's Children 1997. Ankara, 1997.

12. Sivas Governorship Provincial Health Directorate. Health Directorate Statistics Yearbook 1997.Sivas, 1998

13.Yoldaçcan E. Şaşmaz T. Tanır F. Akbaba M. The Evaluation of Some Physical Conditions in the Housing and Surrounding Houses of the Families Migrating to the Doğankent Town. 1. National Congress of Environmental Medicine. Ankara, 1998 